\title{
RESEARCH SERVICES IN EAST AFRICA*
}

\author{
By DR. E. B. WORTHINGTON \\ Scientific Secretary, East Africa High Commission
}

\section{A} PROVISION of the Colonial Development and Welfare Act of 1945 was to earmark up to a million pounds a year for ten years from the British Treasury for research in and on behalf of the Colonial Empire, and in consequence there has been much activity both at home and overseas in designing systems which will enable these funds to be spent in the best way. The purpose of this article is not to recapitulate the work at the London end, centred on the Colonial Office, because this is summarized in the published annual reports of the Colonial Research Committee (now Council) and other advisory committees and councils concerned, and has already been noticed from time to time in Nature. The object is to describe how the new system is working out in a Colonial region, with the advice and assistance of the London authorities.

For this purpose East Africa is taken as the example for several reasons. It comprises three contiguous territories, Kenya, Tanganyika and Uganda, with the island Protectorate of Zanzibar adjoining, so that its components do not suffer from separation by wedges of territory administered by a foreign power, as in the case of the West African region. East Africa has advantages over its neigh. bouring region of Central Africa, because all its component territories are ultimately responsible to the British Parliament through the Secretary of State for the Colonies, whereas Central Africa has to combine two such territories, Northerm Rhodesia and Nyasaland, with Southerm Rhodesia which has Dominion status and is therefore responsible only to itself and does not qualify for grant aid under the Colonial Development and Welfare Act. A further reason for taking East Africa as the example is that, in addition to the territorial Governments, there has been since April 1948 a form of regional Government, the East Africa High Commission, which has its own 'Central Assembly' and secretariat, and is directly responsible for a number of scheduled services, among which inter-territorial research and other scientific activities take a prominent place. The East Africa High Commission has a scientific secretary whose duties are specially concermed with creating a framework within which science can be pursued with a reasonable degree of freedom in the main subjects involved.

Inter-territorial research in East Africa may be said to date from the Ormsby-Gore Commission of 1924, as the result of which the old German scientific station at Amani in Tanganyika was developed into an Agricultural Research Institute having functions in the whole region. Many other Commissions, notably the Hailey Survey of Africa during 1934-37, emphasized the need for more research and for closer co-operation in research. Nevertheless, until the War, investigations were arranged mainly on the basis of technical departments of territorial Governments, within which very few officers could be sufficiently freed from routine duties to undertake research in the true sense. In addition to Amani, however, one or two inter-territorial institutions had * This article summarizes a fuller document on the subject which
was laid on the table at the first meeting of the Central Assembly was laid on the table at the flrst meeting of the
of the East Afrioa High Commission in April 1948 . been established, notably the Central Veterinary Research Institute at Kabete in Kenya, and the Tsetse Fly Research Institute at Shinyanga, which, though primarily headquarters of the Tanganyika Tsetse Department, operated in the adjacent territories as well. During the War, isolation of research workers tended to become more acute; but latterly visits from a number of men eminent in particular scientific spheres have resulted in recommendations, most of which have now been bound into a general scientific framework. The stage is set, therefore, for a big improvement in research, designed to provide a more adequate background of knowledge on which to base development in East Africa.

I would be the last to claim that what we have planned will be sufficient for more than a few years to come. It is significant in this connexion to com. pare the research plan for East Africa with that of a neighbouring region comparable in size, namely, the Belgian Congo. In the group of subjects concermed with primary production from the soil, the Institut National pour l'etude Agronomique du Congo Belge has an annual subvention towards recurrent expenditure of more than a hundred million francs, 3 per cent or so of the whole expenditure on public services in the country. In addition, the Belgian Government has established in 1948 the Institut des Recherches Scientifiques en Afrique Centrale for long-term research in other subjects, with a capital sum of 450 million francs. By comparison, the expenditure on research in East Africa, including grant aid from Colonial Development and Welfare funds, is not expected to reach even 1 per cent of total public expenditure during the next few years. This suggests a scientific deficiency in the British as compared with the Belgian Colonial system which must be made good in course of time.

In the scheme for East African research the first principle being applied is to separate research from executive responsibility wherever possible. Much of the research is being arranged, therefore, in a series of organisations with functions extending over the whole region; and these will be advisory to the executive technical departments, such as those concerned with agriculture, veterinary work, forestry, tsetse control, public works, which will remain responsible to the separate territorial Governments.

The advantages of pooling a good part of the research effort in this way will be several : first, greater efficiency, including savings on capital expenditure and personnel ; secondly, better recruiting prospects, because inter-territorial research organisations will offer wider scope to young scientific workers ; thirdly, easier arrangements for seconding specialists to and from centres of research in Great Britain and the Dominions; and fourthly, better service to the territorial Governments and those interested in using the results of research.

Five inter-territorial research organisations are being established now, concerned with the following subjects : agriculture and forestry; veterinary science and animal husbandry; tsetse flies and trypanosomiasis; fisheries; scientific and industrial research. These do not cover by any means the whole field. They are restricted to the main pro- 
ductive subjects, not because we attribute less weight to subjects of social importance, such as health, sociology and education, but because research on these is at present being arranged direct by the authorities at the Colonial Office, with the East Africa High Commission serving in the capacity of local agent rather than controlling authority. There are, however, several branches of research on social subjects of a long-range character attached to Makerere College in Uganda, which is tending to become the East African University.

It is not intended that every scientific man in East Africa will become part of an inter-territorial research organisation, because it will be necessary for each of the main executive departments, being part of the territorial Governments in each territory, to retain its own group of specialists for routine and advisory work. Whereas the research organisations are likely to initiate new lines of investigation, it is expected, moreover, that territorial departments will become intimately concerned as soon as a branch of research reaches the technological stage, when initial results require testing under a variety of practical field conditions.

The research organisations themselves will be responsible direct to the East Africa High Commission; but each will maintain close contacts on one hand with the territorial technical departments concermed, and on the other with the respective council or committee at the Colonial Office. Ultimately it will no doubt be necessary to have a hierarchy of councils and committees in East Africa, bringing a wide variety of experience to bear on the lines which research should follow. We are not starting with this, however, but are adopting the principle of not holding meetings unless there are important matters for discussion and decision. In practice, of course, many conferences and meetings have to be held, but the permanent system of advisory and executive bodies is being allowed to grow up naturally, following rather than preceding the initiation of actual research.

Certain principles apply to each of the five research organisations enumerated above, and to others which may be established. The concept of the 'Research Organisation' rather than the 'Research Institute' is important as implying that the work will pervade the whole of East Africa and not be concentrated in one building. In each case a headquarters of the organisation is being established at some convenient place, and some activities involving extensive facilities and costly apparatus will inevitably take place at headquarters. But the headquarters will be easy to get away from as well as to reach ; and the object of each research organisation will be to conduct research on behalf of East Africa wherever it can be pursued most efficiently. This may be at a scientific centre in Great Britain or a Dominion, at the headquarters of the organisation in East Africa, at a territorial laboratory or out-station, or in a tent in the bush. Another important point is that our research organisations will be staffed by members of the new Colonial Research Service which is expected to be inaugurated in the near future. The terms of service will involve contributory pensions, so that staff will be transferable without difficulty to and from scientific centres elsewhere, particularly those which subscribe to the F.S.S.U.

Considering the five research organisations in more detail, their designation by initials seems inevitable, and in each case the subject is preceded by E.A.
(East Africa) and followed by R.O. (Research Organisation). The largest is E.A.A.F.R.O. (Agriculture and Forestry), which is directed by Dr. B. A. Keen, and will have also Dr. H. H. Storey, who is returning to active research in Africa after valuable work as secretary for agricultural research at the Colonial Office. This organisation, which will absorb the existing staff and facilities at Amani, is intended to grow during five years to more than forty qualified men of science and a similar number of other European staff. Its main divisions will be concerned with soils, fertilizers, crops and pastures, pests and diseases, animal husbandry, sylviculture and forest products. A new headquarters is to be established at a convenient site in a healthy climate some fifteen miles from Nairobi. where a thousand acres of good land have been made available for the purpose by the Kenya Government. In addition, it is intended to have outstations distributed through East Africa, ultimately one in each main ecological zone, using where possible the existing agricultural and forestry experimental stations of the territorial departments. One section, concermed with taxonomic botany, will have special duties associated with the Royal Botanic Gardens at Kew in helping to prepare a much-needed Flora of East Africa, and the main herbarium will be established at the Coryndon Museum in Nairobi, where it will be easy for reference. For the initial capital expenditure on E.A.A.F.R.O., some $£ 280,000$ are being made available from Colonial Development and Welfare Research funds, and the aggregate recurrent expenditure for the first five years is estimated at $£ 297,000$, of which $£ 165,000$ is likewise to come from Colonial Development and Welfare Research funds, the balance being subscribed by the East African Governments.

Next in the list is E.A.V.R.O. (Veterinary), directed by Dr. E. G. White. In staff this will grow to about half the size of E.A.A.F.R.O. It is concerned with all aspects of animal disease, animal health and husbandry, and the production of biological products, which is already a service extending through a good part of the African continent and elsewhere. A part of E.A.V.R.O. concermed with disease is developing from the former Central Veterinary Research Institute and will continue to be located at Kabete, near Nairobi, where additional buildings are being erected. A new part, concerned with animal husbandry, will have headquarters side by side with those of E.A.A.F.R.O., seven miles from Kabete. Capital expenditure on this organisation is expected to be $£ 125,000$ provided from Colonial Development and Welfare Research funds, and recurrent expenditure for the first five years about $£ 399,000, £ 94,000$ coming from Colonial Development and Welfare Research funds, $£ 80,000$ from the East African Governments and the balance from the sale of biological products.

E.A.T.T.R.O. (Tsetse and Trypanosomiasis) is at present in two sections. Tsetse research is based at Shinyanga in Tanganyika, in charge of Mr. W. $\mathbf{H}$. Potts, with a staff of ten scientific workers and $\mathbf{a}$ similar number of other Europeans; human trypanosomiasis research is some thirty-five miles away Tat inde in charge of Dr. H. Fairbairn, with three men of science. Expenditure for the next five years is estimated at $£ 218,000$, of which two-thirds is voted from Colonial Development and Welfare Research funds and the balance provided by the East African Governments. These two centres have been in existence for many years, and some reorganisation is expected, including the binding 
together of the tsetse and trypanosomiasis research with the separate department of Experimental Tsetse Reclamation, which is in charge of Mr. Napier Bax.

E.A.F.R.O. (Fisheries) is at present quite small, dealing only with research on lakes and rivers. Its director is Mr. R. S. A. Beauchamp, who will have four or five scientific workers on his staff, and the headquarters are at Jinja in Uganda, at the point where the Nile originates from Lake Victoria. Capital expenditure of $£ 64,000$ and recurrent expenditure for five years of $£ 51,000$ are provided in whole from Colonial Development and Welfare Research funds. It is hoped that a fisheries research unit will soon be added for the marine waters of East Africa, and there is also recently established in Kenya a small station on the slopes of Mt. Kenya for investigating the special problems of streams and trout fisheries.

E.A.S.I.R.O. (Scientific and Industrial) will, it is hoped, be one of the most important of the research organisations, its subjects including buildings, roads, secondary industries, food processing and water pollution. Only a part of it yet exists, the East Africa Industrial Research Laboratory, situated in Nairobi, in charge of Mr. H. B. Stent. This organisation is intended ultimately to form a kind of local counterpart of the Department of Scientific and Industrial Research in Great Britain. Clearly, it will not be able to undertake extensive researches of a fundamental character except in special cases which demand proximity to local conditions. Wherever possible, problems arising in East Africa would be passed on to larger centres of research such as those established in Britain by the Department of Scientific and Industrial Research.

There are many scientific subjects of importance to Colonial development which are not covered by these research organisations. To mention a few : meteorology is looked after by the East African Meteorological Department, which includes research in its purview wherever it can be fitted in with the regular activities of recording and disseminating information. Hydrology is another subject of basic importance, and the beginnings of its study on a regional basis exist in a newly established hydrological survey of the Nile Basin within East Africa, necessary in connexion with the project for converting Lake Victoria into the largest reservoir in the world. Geology is still a function of territorial departments which, however, are coming into closer line with each other, aided by annual conferences which have been inaugurated in 1948. The same applies to work on the fauna, for which again annual meetings between game wardens have been started. There is much research progressing on insecticides with particular reference to their use against tsetse flies, this being the responsibility of the Colonial Insecticides Committee in London, which maintains a research unit in East Africa and is initiating a series of trials with aircraft in 1948. The problem of locusts is another subject on which research in East Africa is part of a wider service, in this case international in character. Archæology, in which East Africa has outstanding wealth, still awaits more extensive and more permanent facilities. Finally, there is great need for research on economics and statistics, and the East African Statistical Office, which, like the research organisations, is responsible to the East Africa High Commission, is already in existence and likely to expand.

\section{SCIENTIFIC ASPECTS OF COLONIAL DEVELOPMENT}

$\mathrm{T}$ FiE prasident of the British Association for the Advancement of Science, Sir Henry Tizard, referred in his inaugural address at the Brighton meeting to "our bounden duty, and the only certain way of safeguarding our future so long as we remain a large food-importing country, to develop our Colonial territories, particularly the under-populated African colonies, where the increase in population that would follow the control of disease and the increase of food supply would open fresh markets for international trade". The president of Section E (Geography) of the Association, Lord Rennell of Rodd, spэaking of "Geography as a Social Science, with special reference to Africa", said, "For our own good name, the social geographer must be called on to play his very large part in adapting our changing conceptions of African administration, and in se日king to rationalize the mess which western Europəan nations, including we ourselves, have made in the African continent". His address was followed by a discussion in Section $\mathbf{E}$ on the scientific aspэcts of colonial development, to which a number of the younger geographers, several with expərience of work and conditions in the Colonies, contributed. While recognizing that geography is only one of many sciences which could be, and must be, applied to the problems of the Colonies, the geographers were all agreed that their subject has a very definite and distinctive contribution, though one which has not hitherto been given adequate recognition by those in authority.

As to the nature of the contribution, there was considerable discussion. Some believed in the existence of a 'colonial geography', recognized, according to one speaker, by the governments and universities of all the Colonial Powers, except Great Britain, and particularly by France and the Netherlands: but a majority emphasized that colonial territories call for precisely the same type of geographical investigation as any other part of the world, and that the geographer's particular task is the study of the regional characteristics of different areas. Such a study requires the correlation of numerous branches of science, ranging from geology to social anthropology. One speaker recommended the formation of a single colonial institute, forming a part of one of the Universities of Oxford, Cambridge or London, which would not only be responsible for the training of administrative and technical officers for the Colonies but alse would undertake, or be cognizant of, colonial research in most, if not all, branches of knowledge. In an institute of this type, the geographer, with his interest in widely different aspects of environment and society, would have an important role. Another speaker suggested that in. sufficient use is made at present of the very considerable geographical knowledge of officials and others who have lived for long periods in the Colonies.

Lord Rennell described geography as "both the science and the art which deals with mankind on the earth on which we live". It studies in particular the interaction of physical facts on one hand, and economic, social and political conditions on the other. The influence of physical environment upon human activity is generally most noticeable among more backward people-though even here there is no such 